\title{
A Solar Heating and Cooling System in a Nearly Zero-Energy Building: A Case Study in China
}

\author{
Zhifeng Sun, ${ }^{1,2}$ Yaohua Zhao, ${ }^{1}$ Wei Xu, ${ }^{2}$ Xinyu Zhang, ${ }^{2}$ Huai $\mathrm{Li}^{2}$ Min Wang, ${ }^{2}$ Tao He, ${ }^{2}$ and \\ Dongxu Wang ${ }^{2}$ \\ ${ }^{1}$ College of Architecture and Civil Engineering, Beijing University of Technology, Beijing 100124, China \\ ${ }^{2}$ Institute of Building Environment and Energy, China Academy of Building Research, Beijing 100013, China \\ Correspondence should be addressed to Xinyu Zhang; zxyhit@163.com
}

Received 5 January 2017; Revised 21 April 2017; Accepted 18 May 2017; Published 18 July 2017

Academic Editor: Michel Feidt

Copyright (C) 2017 Zhifeng Sun et al. This is an open access article distributed under the Creative Commons Attribution License, which permits unrestricted use, distribution, and reproduction in any medium, provided the original work is properly cited.

\begin{abstract}
The building sector accounts for more than $40 \%$ of the global energy consumption. This consumption may be lowered by reducing building energy requirements and using renewable energy in building energy supply systems. Therefore, a nearly zero-energy building, incorporating a solar heating and cooling system, was designed and built in Beijing, China. The system included a $35.17 \mathrm{~kW}$ cooling (10-RT) absorption chiller, an evacuated tube solar collector with an aperture area of $320.6 \mathrm{~m}^{2}$, two hot-water storage tanks (with capacities of $10 \mathrm{~m}^{3}$ and $30 \mathrm{~m}^{3}$, respectively), two cold-water storage tanks (both with a capacity of $10 \mathrm{~m}^{3}$ ), and a $281 \mathrm{~kW}$ cooling tower. Heat pump systems were used as a backup. At a value of $25.2 \%$, the obtained solar fraction associated with the cooling load was close to the design target of $30 \%$. In addition, the daily solar collector efficiency and the chiller coefficient of performance (COP) varied from 0.327 to 0.507 and 0.49 to 0.70 , respectively.
\end{abstract}

\section{Introduction}

The building sector accounts for more than $40 \%$ of the global energy consumption [1]. The total energy consumption of Chinese buildings (i.e., 16 billion tons of standard coal) accounts for $20.7 \%$ of the total national end energy consumption [2]. Building energy consumption may be lowered by reducing building energy requirements and using a renewable energy system. However, owing to indoor facilities and human activity, basic heating and cooling loads must be met. The corresponding building energy consumption can be reduced by using a renewable energy system, such as a solar energy system and a heat pump system, which are the most suitable renewable energy systems for the building sector. Heat pump systems are normally driven by grid electricity. Solar energy systems can produce electricity, thermal energy for heating and cooling, and can be used with a chiller to meet building energy requirements. The solar energy systems use less grid electricity than the heat pump systems. Therefore, based on the potential energy-saving effect, a solar heating and cooling system
(SHCS) represents the most desirable option for the building sector $[3,4]$.

An SHCS can supply cooling energy for the chiller during the summer and heat in the winter. A typical SHCS equipped with an absorption chiller is shown in Figure 1. The chiller, solar collector, and thermal energy storage (TES) are the main components of the SHCS, and each influences the performance of the other components. Adsorption chillers and absorption chillers are the two main types of chiller available on the current SHCS market. At values of 0.45 to 0.8 , the coefficient of performance (COP) of absorption cooling systems is better than that (0.2 to 0.6$)$ of adsorption systems [5-11]. Most ( $70 \%$ of) chillers used in European SHCS are equipped with absorption chillers [12], and recent statistics show that the single-effect absorption chiller is a popular choice [5-8, 13]. Cabrera et al. [14] compared the cost of different types of solar collector used in office buildings and hotels in Madrid and Copenhagen, respectively. The results showed that in the case of the parabolic trough solar collectors (PTC), the energy costs for cooling are (i) similar to those of flat plate solar collectors (FPC) and (ii) lower than 


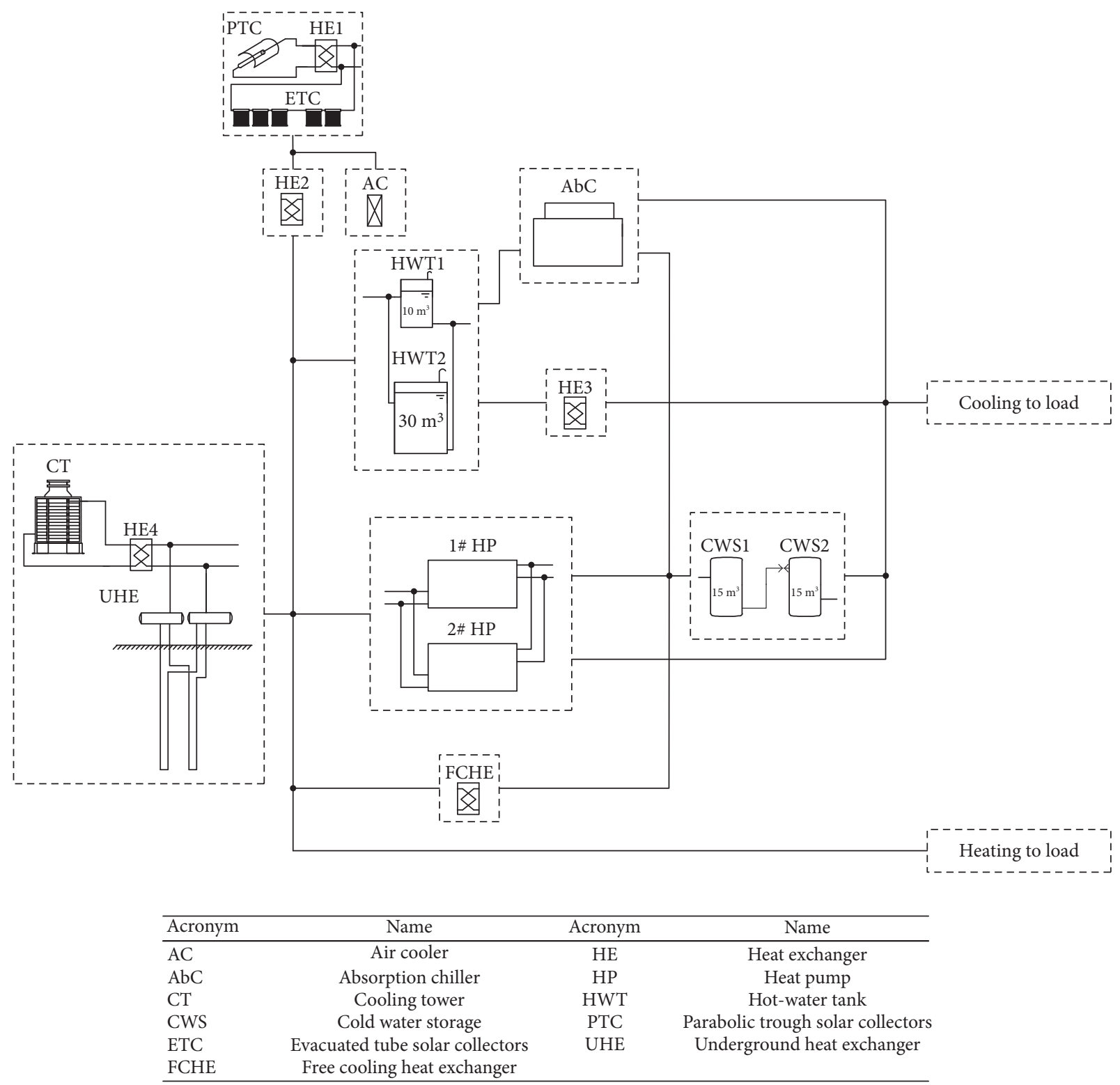

Figure 1: General concept of SHC in nZEB.

those of evacuated tube solar collectors (ETC) and compound parabolic solar collectors (CPC). A study of the solar cooling system in Thailand showed that the cost of the absorption chiller and solar collector represented most of the initial investment [15]. Owing to natural variations in solar irradiation, a TES is essential for controlling fluctuations in the heat transfer fluid temperature supplied to the chiller. If cooling demand is less than the required, TES is used to store the cooling energy for further load requirements. The SHCS consisting of single-effect $\mathrm{LiBr} / \mathrm{H}_{2} \mathrm{O}$ absorption chillers are used in China and other countries (see in Table 1). However, most Chinese SHCS consist of two TESs, and (in recent years) other countries have adopted this practice. Backup energy is crucial for buildings with heating requirements. ETCs are applied in China, whereas FPCs are used mainly in other countries. In fact, China is the largest producer of solar collectors and in 2012,
ETCs comprised $90 \%$ of all collectors [16]. Owing to their high performance and low cost, ETCs are also used in SHCS [15, 17-21].

These studies reveal that most SHCSs have been used in conventional buildings. However, some new buildings have been designed in accordance with the national requirements for energy efficiency. The load requirement of nearly zeroenergy buildings (nZEB) and net zero-energy buildings (NZEB) differs from that of a conventional building. The application of SHCSs in nZEB and/or NZEB has recently been reported. Moldovan et al. [36] proposed a methodology for determining the optimal energy mix for heating and cooling that transforms a low-energy building to nZEB. In that work, a climatic profile with unbalanced heating and cooling demands through the year was considered. The methodology was applied to a research and development laboratory building in Transilvania University of Brasov, and the optimal 
TABLE 1: Characteristics of some conventional SHCSs equipped with a single-effect absorption chiller.

\begin{tabular}{|c|c|c|c|c|c|c|c|}
\hline \multirow{2}{*}{ Site } & \multirow{2}{*}{$\begin{array}{l}\text { Chiller cooling } \\
\text { capacity }(\mathrm{kW})\end{array}$} & \multirow{2}{*}{$\begin{array}{c}\text { Solar collector/ } \\
\text { aperture area }\left(\mathrm{m}^{2}\right)\end{array}$} & \multicolumn{2}{|c|}{ TES/volume $\left(\mathrm{m}^{3}\right)$} & \multirow{2}{*}{$\begin{array}{c}\text { Auxiliary } \\
\text { energy source }\end{array}$} & \multirow{2}{*}{$\begin{array}{c}\text { Air conditioning } \\
\text { building } \\
\text { type/area }\left(\mathrm{m}^{2}\right)\end{array}$} & \multirow{2}{*}{ Reference } \\
\hline & & & Heat & Cool & & & \\
\hline Shenzhen, China & $2 \times 7$ & $\mathrm{ETC} / 76+\mathrm{FPC} / 41$ & 5 & 5 & n.a. & Guest room/80 & {$[22]$} \\
\hline Rushan, China & 100 & ETC/540 & $8+4$ & 6 & Oil boiler & $\begin{array}{l}\text { Exhibition } \\
\text { center/1000 }\end{array}$ & {$[23]$} \\
\hline Tianpu, China & 200 & ETC/812 & 1 & 1200 & $\begin{array}{l}\text { Ground source } \\
\text { heat pump }\end{array}$ & Office/8000 & {$[24]$} \\
\hline Tongzhou, China & 105 & ETC/228 & 10 & 15 & $\begin{array}{l}\text { Ground source } \\
\text { heat pump }\end{array}$ & $\begin{array}{c}\text { Laboratory, } \\
\text { partly office/6552 }\end{array}$ & {$[25]$} \\
\hline Beiyuan, China & 360 & ETC/655 & 40 & 30 & Electric boiler & Office/3000 & [26] \\
\hline Haikou, China & 316 & ETC/1492 & 45 & 30 & Screw chiller & Library/20200 & [27] \\
\hline Qingdao, China & 264 & FPC/638 & 12 & No & $\begin{array}{l}\text { District heating } \\
\text { plant }\end{array}$ & Office/5800 & {$[28]$} \\
\hline Dalian, China & 200 & ETC/733 & $30+24$ & No & Electric heater & $\begin{array}{c}\text { Office } / 2000, \\
\text { Heating area/4120 }\end{array}$ & [29] \\
\hline Shunyi, China & 176 & ETC/523.92 & 15 & 8 & Biomass boiler & Office/1850 & {$[30]$} \\
\hline UC3M, Spain & 35 & FPC/50 & 2 & No & No & House/80 & {$[31]$} \\
\hline CIESOL, Spain & 70 & $\mathrm{FPC} / 160$ & $2 \times 5$ & No & Electric heater & $\begin{array}{c}\text { Institutional } \\
\text { building/1100 }\end{array}$ & {$[4,32]$} \\
\hline Hongkong, China & 4.7 & $\mathrm{FPC} / 38$ & 2.75 & No & Electric heater & n.a. & {$[33]$} \\
\hline $\begin{array}{l}\text { Reunion Island, } \\
\text { France }\end{array}$ & 30 & $\begin{array}{l}\text { Double glazed } \\
\text { FPC/90 }\end{array}$ & 1.5 & 1 & No & Classroom/216 & {$[34]$} \\
\hline Cardiff, UK & 4.5 & ETC/12 & No & 1 & No & Office/82 & [19] \\
\hline New Mexico, USA & 70 & $\mathrm{FPC} / 124+\mathrm{ETC} / 108$ & 34 & $7 \times 50$ & $\begin{array}{l}\text { District energy } \\
\text { supply plant }\end{array}$ & $\begin{array}{c}\text { Educational } \\
\text { building/7000 }\end{array}$ & {$[20,35]$} \\
\hline $\begin{array}{l}\text { Oberhausen, } \\
\text { Germany }\end{array}$ & 35.17 & ETC/108 & 6.8 & 1.5 & No & Office/108 & {$[21]$} \\
\hline SERT, Thailand & 35.17 & ETC/72 & 0.4 & 0.2 & LPG boiler & Office/n.a. & {$[15]$} \\
\hline
\end{tabular}

energy mix for nZEB was determined from numerical simulations and in-field meteorological data. In addition, Gallo et al. [37] analyzed the integration of photovoltaic (PV) solar domestic hot water and air conditioning systems in NZEB in Spain. The simulation results showed that PV systems play an important role in reducing the use of fossil fuels in NZEB and, hence, these systems may also play a key role in China.

This work focuses on the realization of nZEB in China. The energy supply systems applied in the demonstration buildings were analyzed, especially the concept of SHCS during the design and operating phases. Moreover, the performance of the SHCS was evaluated, via the monitoring data, and optimal conditions for further improving the efficiency of the system were suggested.

\section{Building Description, System Design, and Measurements}

2.1. Building Description. The building is located at $39^{\circ} 92^{\prime} \mathrm{N}$ latitude, $116^{\circ} 46^{\prime} \mathrm{E}$ longitude in Beijing and, based on the Koppen climate classification, experiences a Cwa (warm temperature, dry winter, and warm summer). The outdoor parameters for system design in Beijing (in accordance with Chinese standard GB 50736-2012: design code for heating
TABLE 2: Outdoor climate parameters for system design in Beijing.

\begin{tabular}{lcc}
\hline Parameters & Unit & Value \\
\hline Temperature for heating & ${ }^{\circ} \mathrm{C}$ & -7.6 \\
Temperature for ventilation in winter & ${ }^{\circ} \mathrm{C}$ & -3.6 \\
Temperature for air conditioning in winter & ${ }^{\circ} \mathrm{C}$ & -9.9 \\
Relative humidity for air conditioning in winter & $\%$ & 44 \\
Dry-bulb temperature for air conditioning in summer & ${ }^{\circ} \mathrm{C}$ & 33.5 \\
Wet-bulb temperature for air conditioning in summer & ${ }^{\circ} \mathrm{C}$ & 26.4 \\
Temperature for ventilation in summer & ${ }^{\circ} \mathrm{C}$ & 29.7 \\
Relative humidity for ventilation in summer & $\%$ & 61 \\
Average temperature for air conditioning in summer & ${ }^{\circ} \mathrm{C}$ & 29.6 \\
Average wind speed in summer & $\mathrm{m} / \mathrm{s}$ & 2.1 \\
Average wind speed in winter & $\mathrm{m} / \mathrm{s}$ & 2.6 \\
\hline
\end{tabular}

ventilation and air conditioning of civil buildings) are shown in Table 2. The four-floor office building, with a total cooling area of $4025 \mathrm{~m}^{2}$, has 40 office rooms, one conference room, and four meeting rooms.

Details of the building envelope are provided in the following section. 
The walls in this building were externally insulated. In addition, the external wall has a decorative coating $(2 \mathrm{~mm})$, and the outer layer consists of aerated concrete blocks $(200 \mathrm{~mm})$ and a decorative board integrated with an ultrathin vacuum insulation board $(25 \mathrm{~mm})$. Values of $0.24 \mathrm{~W} /\left(\mathrm{m}^{2} \cdot \mathrm{K}\right)$ and $0.16 \mathrm{~W} /\left(\mathrm{m}^{2} \cdot \mathrm{K}\right)$ were obtained for the onsite test-yield heat transfer coefficient of the external wall and roof, respectively. Furthermore, the aluminum alloy window used in the building has the following characteristics: general heat transfer coefficient: $1.0 \mathrm{~W} /\left(\mathrm{m}^{2} \cdot \mathrm{K}\right)$, shading coefficient: 0.26 , window glass: tempered glass with a $5 \mathrm{~mm}$ lowemission film, vacuum layer: $2 \mathrm{~mm}$, glass: $5 \mathrm{~mm}$, air layer: $27 \mathrm{~mm}$, and tempered glass: $5 \mathrm{~mm}$. The vacuum glass used in the window had a transmittance of $38 \%$ and an airtightness performance rank of 8 (based on the Chinese national energy efficiency standard GB 50189-2005: design standard for energy efficiency of public buildings). The measures aimed at reducing the thermal bridge in the structure were also taken to further lower the building energy requirements for heating and cooling.

2.2. Load Requirement and System Scheme. The detailed design of the building envelope lists the requirements for the heating and cooling loads. For example, fresh air and sunlight are necessary for people inside the building and (although resulting in energy consumption for cooling) helpful in lowering the heating requirement, respectively. The loads for heating in winter and cooling in summer were calculated in accordance with the Chinese energy efficiency standard (GB 50189-2005: design standard for energy efficiency of public buildings). The load is composed of three components, namely, the basic heating/cooling load, load for fresh-air treatment, and load for humidity treatment. The basic heating/cooling load is generated by the building envelope, whereas the other two components vary with the number of people in the building. A space heating load of $66574.7 \mathrm{~W}\left(16.54 \mathrm{~W} / \mathrm{m}^{2}\right)$ was calculated, and a fresh-air requirement of $10,570 \mathrm{~m}^{3} / \mathrm{h}$ yielded a heating load of $90069.5 \mathrm{~W}$. In addition, a value of $-135 \mathrm{~kg} / \mathrm{h}$ (“-” refers to the humidity that must be removed from the building) was determined for the load associated with dehumidification. Therefore, the maximal hourly cooling load, fresh-air requirement, cooling load for fresh-air treatment, and load for dehumidification were $148934.8 \mathrm{~W}, 10,570 \mathrm{~m}^{3} / \mathrm{h}, 26062.9 \mathrm{~W}$, and $-129.99 \mathrm{~kg} / \mathrm{h}$, respectively. The HVAC system should fulfill the heating and cooling requirements. The cooling load, $148934.8 \mathrm{~W}\left(37.00 \mathrm{~W} / \mathrm{m}^{2}\right)$, is higher than the heating load $(66574.7 \mathrm{~W})$. Therefore, the capacity of the system is decided by the cooling load and the fresh-air treatment load in the summer. Fresh air is essential for people inside an extremely airtight building, and hence the load for this treatment is required throughout the year.

2.3. General Concept of System Design. The general concept of an SHCS is shown in Figure 1. The SCHS consists of six circuits, namely, the solar collecting circuit, heat storage circuit, heat to absorption chiller circuit, supply heat/cold energy to building circuit, underground heat exchanger circuit, and cooling tower circuit. In summer time, the solar collectors collect the heat from the sun and the water in the hot-water tanks are heated. Moreover, the absorption chiller starts working when the temperature in the tanks reach the start temperature required for driving this operation. The resulting cooling energy is stored in the cold-water tank and is later supplied to the building. When the cooling requirement is extremely high, the heat pumps start to work. In winter time, heat is supplied to the building if the temperature in HTWs is sufficiently high. Otherwise, the heat will be used to keep the solar collectors warm during winter nights. The heat supplied to the building comes mainly from the heat pumps.

2.4. Solar Collector System. The roof of the building was divided into two parts. Six light tubes, for guiding natural light into the conference room, were installed at the south of the roof covering the room. The medium-temperature PTC, with an aperture area of $30 \mathrm{~m}^{2}$, was installed on the northern part of the roof, and heat transfer oil was used as the heat transfer medium.

The U-type evacuated tube solar collector with a CPC reflector was installed on the lower part of the roof, which was filled with ETCs to maximize heat absorption from the sun. The ETC field, $320.6 \mathrm{~m}^{2}$ (Figure 2), was tilted by $25^{\circ}$ with respect to the roof. When the cooling load is higher than the heating load, this angle enables high heat absorption (by the solar collector) in the summer.

The ETC used in the system was developed as part of the 11th Chinese national scientific project-Large Scale Application of Solar Energy in Buildings (number 2006BAJ01A11). The instantaneous efficiency curve can be described by the following equation:

$$
\eta=0.691-0.830 U-0.0035 G(U)^{2},
$$

where $\eta, G$, and $U$ are the instantaneous efficiency of the solar collector, solar irradiance $\left(\mathrm{W} / \mathrm{m}^{2}\right)$, and the reduced temperature difference $\left(\mathrm{m}^{2} \cdot \mathrm{K} / \mathrm{W}\right)$, respectively.

In summer and winter, water and an ethylene glycol aqueous solution (to prevent freezing), respectively, are used as the heat transfer media in the circuit. Overheating of the ETC and solar system in summer was prevented by using a rooftop heat exchanger to release the heat to the surrounding air.

2.5. Thermal Energy Storage. Based on the experience from projects in China and other countries [15, 19, 21,34], two types of TES were used in this system. The air conditioning equipment was tested in a lab, and a $30 \mathrm{~m}^{3}$ rectangular steel water tank was reused for heat storage. The aim here was to ensure that a rapid temperature increase and consequent cold-water generation were induced by the heat absorbed from the sun (by the solar collector) in the morning. A $10 \mathrm{~m}^{3}$ rectangular steel water tank, which was also used in the heating time, was added. A $50 \mathrm{~mm}$ rubber sponge was used as the insulation material for the tanks. The water temperature for the heating requirement is lower than the water temperature required to generate cooling water from the absorption. Moreover, the solar energy is fully utilized by using two tanks during the heating season. 


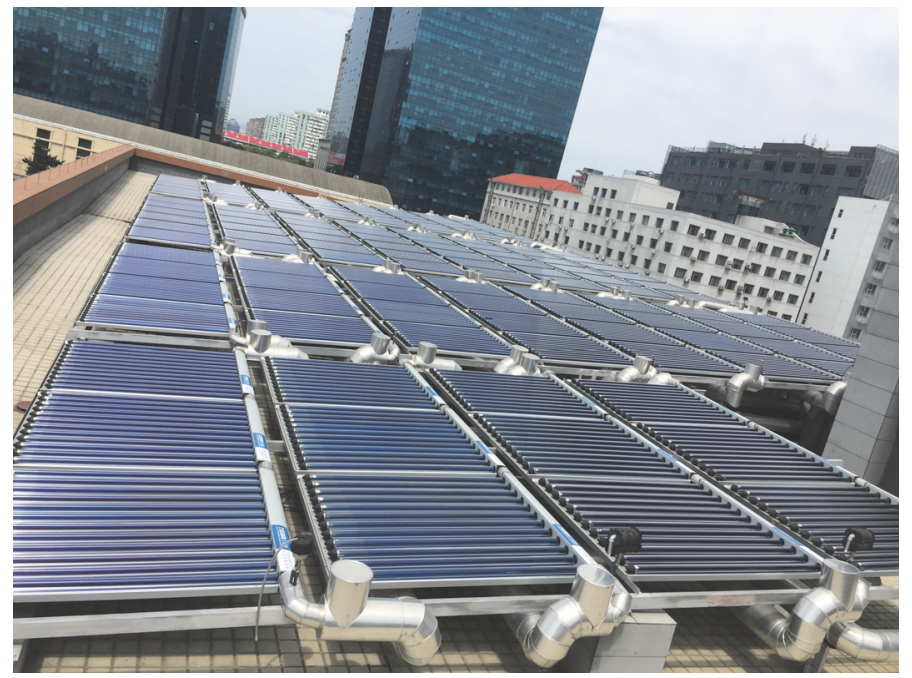

Figure 2: Photograph of evacuated tube solar collector with CPC reflectors.

Furthermore, to maximize solar energy absorption and reduce heat loss, two $10 \mathrm{~m}^{3}$ cylindrical tanks were used as cooling storage. These tanks can store an hour of cooling energy generated by the absorption chiller. A $50 \mathrm{~mm}$ rubber sponge insulation material was also used. The heat storage and cooling storage tanks were installed in the conventional building and new building, respectively. During the intermediate seasons, heat from the sun was used to heat the fresh air of the room from winter to the cooling season. Similarly, from summer to the heating season, the cooling energy from the absorption chiller was used to cool the fresh air of the building.

The peak-valley electricity price for Beijing was adopted. The nighttime valley and peak hour electricity prices of this building are $0.3818 \mathrm{RMB} / \mathrm{kWh}$ and $1.4407 \mathrm{RMB} / \mathrm{kWh}$, respectively. Based on the design of the system control, money is saved because the heat pump operates during the night to store energy in the cooling tank.

2.6. Absorption Chiller and Cooling Tower. A single-effect $\mathrm{LiBr}-\mathrm{H}_{2} \mathrm{O}$ absorption chiller (WFC-10 RT, YAZAKI Corporation) with a rated cooling capacity of $35.17 \mathrm{~kW}$ (10-RT) was used in the HVAC system. According to the manufacturer, a COP of 0.7 is obtained when the chiller operates at a hot-water temperature, cooling water temperature, and output temperature of $87^{\circ} \mathrm{C}, 29^{\circ} \mathrm{C}$, and $8^{\circ} \mathrm{C}$, respectively. The cooling capacity of the chiller accounts for more than $30 \%$ of the cooling load.

The cooling tower, which rejects heat from the chiller water to the ambient air, has a capacity of $281 \mathrm{~kW}$ at $32 / 37^{\circ} \mathrm{C}$ and an ambient air wet-bulb temperature of $28^{\circ} \mathrm{C}$.

2.7. Heat Pump and Other Concepts. A ground source heat pump system was used in the nZEB as a principal energy source for cooling and heating. While the cooling energy from the absorption chiller cannot meet the load requirement, the heat pumps start. Two heat pumps were used, namely, (i) $99.5 \mathrm{~kW}$ (cooling)/103.7 kW (heating) and (ii) $50 \mathrm{~kW}$ (cooling) $/ 51.7 \mathrm{~kW}$ (heating). The ground heat exchanger system consisted of 20 double $80 \mathrm{~m}$ (depth) and 50 single $60 \mathrm{~m}$ (depth) U pipes.

As the building is for demonstration purposes, the following concepts were considered.

A free cooling concept was used for the building. In this case, a flat plate heat exchanger was installed in the cooling energy supply system. During the cooling season, and based on the load requirement, the energy from the cooling tower and underground pipe heat exchangers supplies cooling energy to the building through this exchanger. This reduces the cost of cooling with marginal pump power consumption.

A fresh-air supply system was used in the building. This building serves as a demonstration, and, therefore, different air conditioning units were used on different floors. In addition, variable refrigerant volume systems, radiation floor systems, radiation ceiling systems, and water loop heat pump systems were used on the first, second, third, and fourth floors, respectively.

2.8. Energy Consumption Monitoring System. An energy management system (EMS) was installed in the energy supply system. The EMS consists of three components: meters, data collectors, and energy consumption data management software. The electricity consumption, water volume, and energy for heating and cooling were measured and recorded. During electricity consumption monitoring, the electricity for air conditioning, lighting, plugs, power for the lift, and power for the EMS was measured. The electricity generated by the PV system (capacity of only $2.88 \mathrm{kWp}$ ), connected to the circuit for illumination, was also measured. The energy consumption monitoring system consisted of 68 electricity meters, 40 heat meters, and two water meters.

\section{Parameters}

To understand the performance of the system, the test results are presented by using a simple data reduction, as described in [38]. The useful energy gained from the sun by the solar collector can be expressed as 


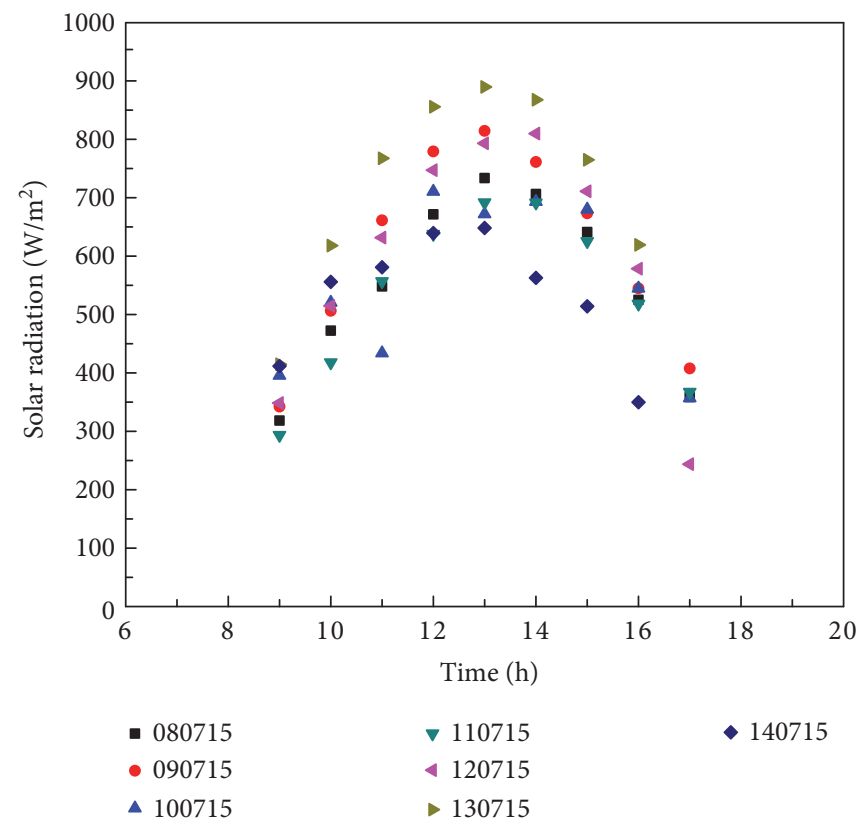

Figure 3: Incident solar irradiation from 08 July 2015 to 14 July 2015.

$$
q_{j}=\sum_{i=1}^{n} \dot{V}_{j i} \rho_{w} c_{p w}\left(t_{d j i}-t_{b j i}\right) \Delta T_{j i} \times 10^{-6},
$$

where $q_{j}$ is useful energy gained (MJ), $\dot{V}_{j i}$ is average flow rate $\left(\mathrm{m}^{3} / \mathrm{s}\right)$ of the solar collection system, $c_{p w}$ is constant specific heat $\left(\mathrm{J} / \mathrm{kg} \cdot{ }^{\circ} \mathrm{C}\right)$ of the heat transfer fluid, $\rho_{w}$ is density $(\mathrm{kg} /$ $\mathrm{m}^{3}$ ) of the heat transfer fluid, $t_{d j i}$ is inlet temperature $\left({ }^{\circ} \mathrm{C}\right)$ of the solar collector, $t_{b j i}$ is outlet temperature $\left({ }^{\circ} \mathrm{C}\right)$ of the solar collector, $\Delta T_{j i}$ is recorded time interval (s, $\Delta T_{j i}$ should be less than $600 \mathrm{~s}$ ), and $n$ is total number of recorded data points. $q_{j}$ can be determined from the flow rate, $t_{d j i}$ and $t_{b j i}$ of the solar collection system, or by using a heat meter.

The efficiency $(\eta)$ of the solar collection system may be expressed as follows:

$$
\eta=\frac{q_{j}}{A H}
$$

where $A$ and $H$ are the area $\left(\mathrm{m}^{2}\right)$ of the collector and the solar irradiation $\left(\mathrm{MJ} / \mathrm{m}^{2}\right)$ on the aperture area of the collector.

The heating energy consumed by the absorption chiller may be expressed as follows:

$$
\dot{Q}_{r}=\sum_{i=1}^{n} \dot{V}_{r i} \times \rho_{w} \times c_{p w} \times\left(t_{d r i}-t_{b r i}\right) \times \Delta T_{r i} \times \frac{10^{-3}}{\Delta T},
$$

where $\dot{Q}_{r}$ is heating energy $(\mathrm{kW})$ consumed by the chiller, $\dot{V}_{r i}$ is average flow rate $\left(\mathrm{m}^{3} / \mathrm{s}\right)$ of the system, $t_{d r i}$ is temperature $\left({ }^{\circ} \mathrm{C}\right)$ of the water supplied to the chiller, $t_{b r i}$ is temperature $\left({ }^{\circ} \mathrm{C}\right)$ of the water returned from the chiller, $\Delta T_{r i}$ is recorded time interval (s, which should be less than $600 \mathrm{~s}$ ), and $\Delta T_{t}$ is total recording time (s).

The cooling energy supplied by the absorption chiller is determined from

$$
\dot{Q}_{l}=\sum_{i=1}^{n} \dot{V}_{l i} \times \rho_{w} \times c_{p w} \times\left(t_{d l i}-t_{b l i}\right) \times \Delta T_{l i} \times \frac{10^{-3}}{\Delta T_{t}}
$$

where $\dot{Q}_{l}$ is cooling energy (kW) supplied by the chiller, $\dot{V}_{l i}$ is average flow rate $\left(\mathrm{m}^{3} / \mathrm{s}\right)$ of the system, $t_{d l i}$ is temperature $\left({ }^{\circ} \mathrm{C}\right)$ of the water returned to the chiller, $t_{b l i}$ is temperature $\left({ }^{\circ} \mathrm{C}\right)$ of the water provided by the chiller, and $\Delta T_{l i}$ is the recording time interval (s), which should be less than $600 \mathrm{~s}$.

Following AHH et al. [21], the COP can be defined as the ratio of the evaporator cold capacity $\dot{Q}_{l}$ to the heat input generation $\dot{Q}_{r}$ :

$$
\mathrm{COP}=\frac{\dot{Q}_{l}}{\dot{Q}_{r}} .
$$

The solar fraction of this SHC is given as

$$
f=\frac{\dot{Q}_{l}}{\dot{Q}_{t}}
$$

where the solar fraction, $f$, corresponds to the ratio of the cooling/heating energy from absorption to the total cooling/heating energy supplied to the building (i.e., $\dot{Q}_{t}$ is the cooling energy supplied to the building in summer and the heating energy in winter).

\section{Results and Discussion}

4.1. Collector Performance. The SHCS was evaluated via operating parameters (such as the solar irradiation and ambient temperature), which were recorded over a few days. The daily maximal solar irradiation ranged from $648 \mathrm{~W} / \mathrm{m}^{2}$ to $890 \mathrm{~W} / \mathrm{m}^{2}$ (Figure 3), while the average and maximal ambient temperatures ranged from $30.9^{\circ} \mathrm{C}$ to $35.0^{\circ} \mathrm{C}$ and $32.2^{\circ} \mathrm{C}$ to $39.0^{\circ} \mathrm{C}$ (Figure 4 ), respectively. In addition, the nominal 


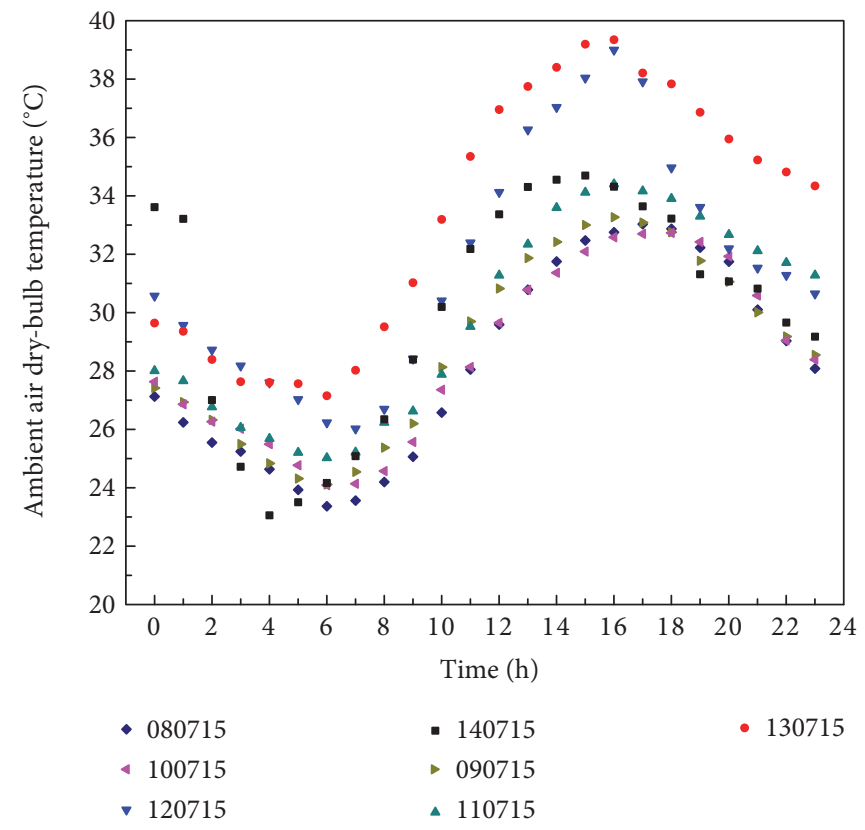

Figure 4: Ambient air dry-bulb temperature from 08 July 2015 to 14 July 2015.

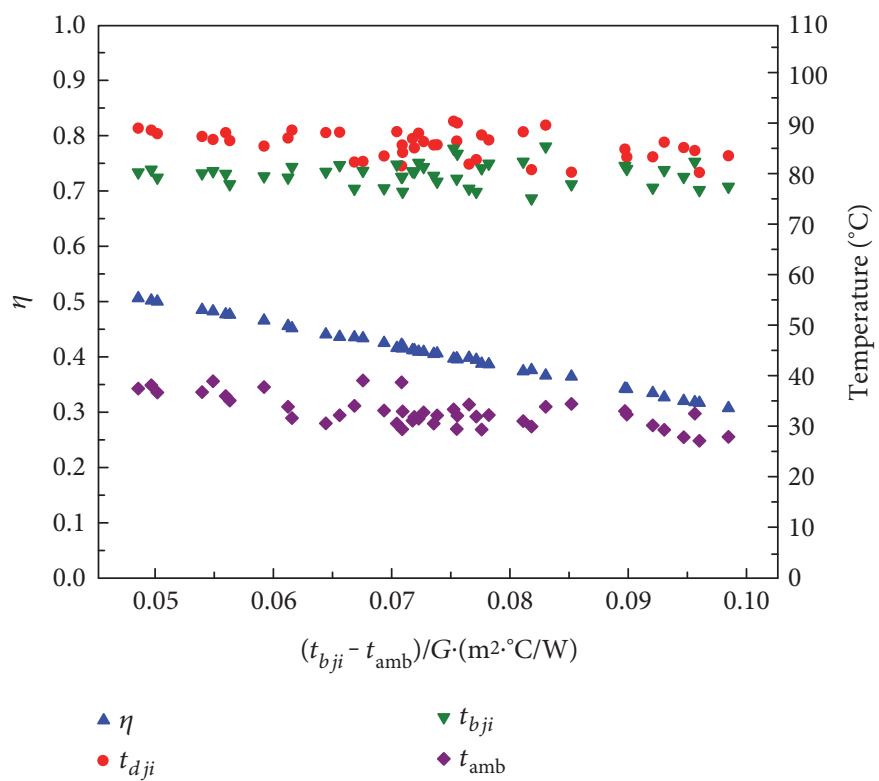

Figure 5: Field efficiency of instantaneous collectors.

heat transfer fluid temperature of absorption was $\sim 87^{\circ} \mathrm{C}$, and the efficiency of collector field ranged from 0.327 to 0.507 . This change in efficiency (see Figure 5) resulted mainly from changes in the meteorological conditions. The solar collector exhibited a higher heat loss than that reported by the manufacturer, but performed better under clear-sky conditions. Furthermore, dust collected on the CPC reflector persisted even after heavy rain, and in the summer of 2015, steam was released (via evaporation) from the collector fields. These factors all contributed to a decrease in the collector performance. Optimization of the pipe arrangements and regular cleaning of the collector and CPC reflector surfaces will reduce the potential for evaporation and enhance the collector efficiency, respectively.

4.2. Performance of the SHC. The operating parameters recorded from 08 July 2015 to 14 July 2015 are shown in Figure 6. The figure shows the measured temperature of the inlet water to the absorption chiller generator $\left(t_{d r i}\right)$, temperature of the outlet water from the absorption chiller evaporator $\left(t_{b l i}\right)$, heat supplied by solar energy to the chiller $\left(\dot{Q}_{r}\right)$, and cooling power load produced by the absorption chiller during 

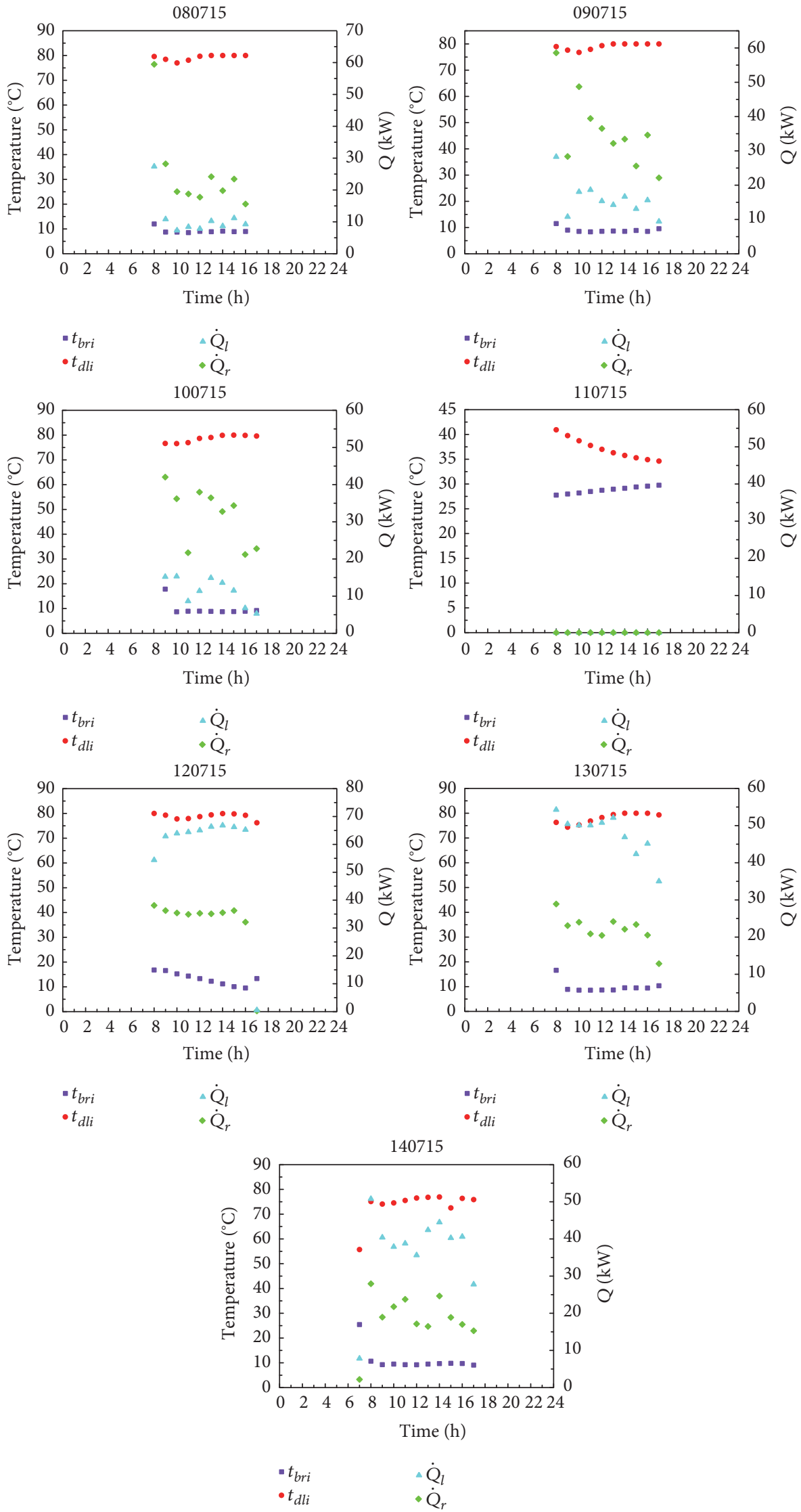

Figure 6: Instantaneous characteristics of SHC from 08 July 2015 to 14 July 2015. 


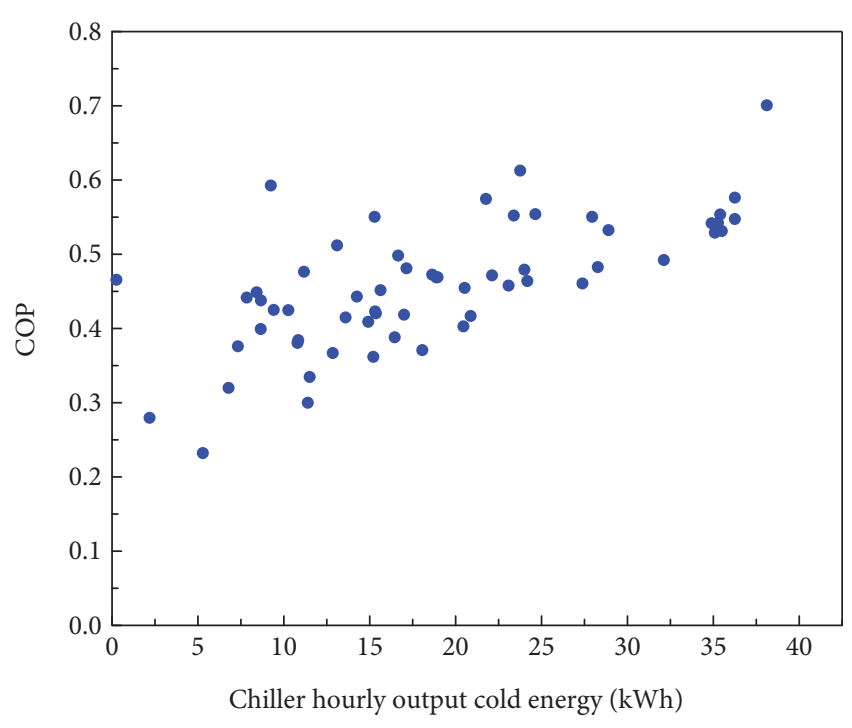

FIGURE 7: Dependence of the chiller daily average COP on the cold energy demand from 08 July 2015 to 14 July 2015.

the day time. The solar collector system and chiller were not operated during the day of 11 July 2015.

The chiller is started at a driving hot-water temperature of $\sim 77^{\circ} \mathrm{C}$ (see Figure 6), which lies in the drivingtemperature range $\left(70^{\circ} \mathrm{C}-95^{\circ} \mathrm{C}\right)$ specified by the chiller manufacturer. However, except for the day of 12 July 2015, the output cold power is lower than the nominal value. The operating data for 12 July 2015 show that the input heat power is close to the nominal value, and the temperature of the water to the chiller generator increased from $77.8^{\circ} \mathrm{C}$ to $80.0^{\circ} \mathrm{C}$ (see Figures 6-7); at the same time, the cold temperature to the load decreased from $16.8^{\circ} \mathrm{C}$ to $9.5^{\circ} \mathrm{C}$. In addition, the calculated COP ranged from 0.49 to 0.70 and the maximum COP reached the nominal value. The inlet temperature and the heat power supplied to the chiller generator were both lower than the nominal value reported by the chiller manufacturer. Therefore, the chiller temperature and cold power to load were higher and lower, respectively, than the nominal value. However, based on the design concept, the solar collector system can satisfy both the temperature and heat-power requirements. Subsequent investigation of SHCS will focus on determining the underlying principle of and optimizing the SHCS operation.

The variation in COP on the aforementioned days is shown in Figure 7. As reported in a previous study [21], the COP varied with the output cold power supplied to the load. Furthermore, a maximum COP of 0.7 (the nominal value supplied by the chiller manufacturer) was obtained under clear-sky conditions.

A design target of $30 \%$ was set for the cooling energy covered by the absorption chiller, but a value of $25.2 \%$ was obtained during actual testing in the summer of 2015. The heat fluid of solar collector is water; during the winter of 2014-2015, most of the heat from solar energy was used to keep the solar collector warm during the night (less heat was used by the building).
4.3. Free Cooling Concept and PV System Performance. Though many technical measures were instituted for this nZEB, most of these measures were only demonstrated. For example, the free cooling concept, that is, the ground heat exchanger and the cooling tower constituting the main cooling source, fell short of expectations. A significant amount of work is required to fully exploit this concept. During operation, the solar thermal system and heat pump system are the main cooling/heating source.

The building-integrated photovoltaic was installed on the south wall. In 2015, the total power and daily average output from the PV system were $1031.43 \mathrm{kWh}$ and $2.83 \mathrm{kWh}$, respectively. The output power is used for illumination of the public areas, and, hence, its contribution to the reduction of electricity consumption is trivial.

\section{Conclusions}

We presented an initial performance assessment of a solar heating and cooling system in an nZEB building. Values of $13,006 \mathrm{kWh}$ and $38,656 \mathrm{kWh}$ were recorded for the cooling energy supplied by the SHCS and the heat pumps, respectively. Furthermore, a value of $25.2 \%$, which is very close to the design target of $30 \%$, was obtained for the rate of SHCS contribution. The electricity meter revealed that the general energy consumption for cooling, heating, and light from 2014 to 2015 was $<23 \mathrm{kWh} / \mathrm{m}^{2}$. During the intermediate season, the SHCS met most of the load requirements for fresh-air treatment. Although the free cooling concept was adopted, this concept fell short of expectations under actual operating conditions, although the SHCS played an important role in conventional energy consumption reduction.

On sunny days, the daily efficiency of the solar collector and the COP of the chiller varied from 0.327 to 0.507 and 0.49 to 0.70 , respectively. The energy requirements must be accurately predicted for a solar heating and cooling system applied in this nZEB building. The load requirements and characteristics of an nZEB differ from those of a conventional building. In the case of a conventional building, the load requirement and changes thereof are affected by outdoor conditions. In the case of an nZEB, changes in the outdoor temperature and solar irradiation have only a modest effect on the cooling load. The main load requirements of an nZEB are to (i) remove heat from equipment, such as personal computers, and (ii) provide energy for fresh-air treatment, which depends on the number of people inside the building. The load characteristics and capacity should be considered during the selection of a solar thermal system. In addition, TES is essential for balancing the load requirement and energy supply of the SHCS in an nZEB.

This building is a demonstration of an nZEB, and the energy system (including the SHCS) is under commission. The optimal operational measurements will be performed in accordance with the recorded data. Further work on the SHCS in an nZEB will focus on improving the efficiency of the solar collector and fully exploiting the use of TES. The phase change material will be carefully selected. 


\section{Nomenclature}

\begin{tabular}{|c|c|}
\hline A: & Aperture area of the solar collector, $\mathrm{m}^{2}$ \\
\hline$A_{s}:$ & Collector area per target cold capacity, $\mathrm{m}^{2} / \mathrm{kW}$ \\
\hline$c_{p w}:$ & Specific heat at constant pressure, $\mathrm{kJ} /\left(\mathrm{kg} \cdot{ }^{\circ} \mathrm{C}\right)$ \\
\hline$G:$ & $\begin{array}{l}\text { Solar irradiation on the aperture of the solar } \\
\text { collector, } \mathrm{W} / \mathrm{m}^{2}\end{array}$ \\
\hline$H:$ & $\begin{array}{l}\text { Solar irradiation on the aperture of the solar } \\
\text { collector, } \mathrm{MJ} / \mathrm{m}^{2}\end{array}$ \\
\hline$\dot{V}_{j i}:$ & $\begin{array}{l}\text { Average flow rate of the solar collecting sys- } \\
\text { tem }, \mathrm{m}^{3} / \mathrm{s}\end{array}$ \\
\hline$\dot{V}_{l i}:$ & $\begin{array}{l}\text { Average flow rate of the cooling water from } \\
\text { the chiller, } \mathrm{m}^{3} / \mathrm{s}\end{array}$ \\
\hline$\dot{V}_{r i}:$ & $\begin{array}{l}\text { Average flow rate of the heating water to the } \\
\text { chiller, } \mathrm{m}^{3} / \mathrm{s}\end{array}$ \\
\hline$\dot{Q}_{l}:$ & Cooling energy supplied by the chiller, kW \\
\hline$\dot{Q}_{r}:$ & Heating energy consumed by the chiller, $\mathrm{kW}$ \\
\hline$Q_{j}:$ & $\begin{array}{l}\text { Useful energy gained by the solar collecting } \\
\text { system, MJ }\end{array}$ \\
\hline$\dot{Q}_{t}:$ & $\begin{array}{l}\text { Cooling or heating energy consumed by the } \\
\text { building, } \mathrm{kW}\end{array}$ \\
\hline$U:$ & The reduced temperature difference, $\mathrm{m}^{2} \cdot \mathrm{K} / \mathrm{W}$ \\
\hline$t_{\mathrm{amb}}:$ & Ambient temperature, ${ }^{\circ} \mathrm{C}$ \\
\hline$t_{b j i}:$ & $\begin{array}{l}\text { Supply temperature of the solar collecting } \\
\text { system, }{ }^{\circ} \mathrm{C}\end{array}$ \\
\hline$t_{b l i}:$ & $\begin{array}{l}\text { Supply water temperature from the evapora- } \\
\text { tor of absorption chiller, }{ }^{\circ} \mathrm{C}\end{array}$ \\
\hline$t_{b r i}:$ & $\begin{array}{l}\text { Return water temperature from the generator } \\
\text { of absorption chiller, }{ }^{\circ} \mathrm{C}\end{array}$ \\
\hline$t_{d j i}:$ & $\begin{array}{l}\text { Outlet temperature of the solar collecting } \\
\text { system, }{ }^{\circ} \mathrm{C}\end{array}$ \\
\hline$t_{d l i}:$ & $\begin{array}{l}\text { Return water temperature to the evaporator } \\
\text { of absorption chiller, }{ }^{\circ} \mathrm{C}\end{array}$ \\
\hline$t_{d r i}:$ & $\begin{array}{l}\text { Supply water temperature to the generator of } \\
\text { absorption chiller, }{ }^{\circ} \mathrm{C} \text {. }\end{array}$ \\
\hline \multicolumn{2}{|c|}{ Greek symbols } \\
\hline$\rho_{w}:$ & Density of the heat transfer media, $\mathrm{kg} / \mathrm{m}^{3}$ \\
\hline$\eta:$ & Efficiency of the solar collecting system, \% \\
\hline & Recording time interval, $s$ \\
\hline$\Delta T_{t}:$ & Total recording time, s. \\
\hline
\end{tabular}

\section{Abbreviations}

COP: Coefficient of thermal performance for the absorption chiller

CPC: Compound parabolic solar collector

EMS: Energy management system

ETC: Evacuated tube solar collector

FPC: Flat plate solar collector

HVAC: Heat ventilation and air conditioning

nZEB: Nearly zero-energy building

NZEB: Net zero-energy building

PTC: Parabolic trough solar collector

SHCS: Solar heating and cooling system

TES: Thermal energy storage.

\section{Conflicts of Interest}

The authors declare that they have no conflicts of interest.

\section{Acknowledgments}

This work was funded by the Ministry of Science and Technology, China (2016YFC0700405).

\section{References}

[1] United Nations Environment Program, Buildings and Climate Change, Paris, 2009.

[2] W. G. Cai, Y. Wu, Y. Zhong, and H. Ren, "China building energy consumption: situation, challenges and corresponding measures," Energy Policy, vol. 37, pp. 2054-2059, 2009.

[3] U. Desideri, S. Proietti, and P. Sdringola, "Solar-powered cooling systems: technical and economic analysis on industrial refrigeration and air-conditioning applications," Applied Energy, vol. 86, pp. 1376-1386, 2009.

[4] S. Rosiek and F. J. Batlles, "Renewable energy solutions for building cooling, heating and power system installed in an institutional building: case study in southern Spain," Renewable and Sustainable Energy Reviews, vol. 26, pp. 147168, 2013.

[5] A. Ghafoor and A. Munir, "Worldwide overview of solar thermal cooling technologies," Renewable and Sustainable Energy Reviews, vol. 43, pp. 763-774, 2015.

[6] Y. Fan, L. Luo, and B. Souyri, "Review of solar sorption refrigeration technologies: development and applications," Renewable and Sustainable Energy Reviews, vol. 11, pp. 1758-1775, 2007.

[7] H.-M. Henning, "Solar assisted air conditioning of buildings an overview," Applied Thermal Engineering, vol. 27, pp. 17341749, 2007.

[8] X. Q. Zhai and R. Z. Wang, "A review for absorbtion and adsorbtion solar cooling systems in China," Renewable and Sustainable Energy Reviews, vol. 13, pp. 1523-1531, 2009.

[9] I. Sarbu and C. Sebarchievici, "Review of solar refrigeration and cooling systems," Energy and Buildings, vol. 67, pp. 286297, 2013.

[10] D. S. Kim and C. A. I. Ferreira, "Solar refrigeration options - a state-of-the-art review," International Journal of Refrigeration, vol. 31, pp. 3-15, 2008.

[11] R. Z. Wang, T. S. Ge, C. J. Chen, Q. Ma, and Z. Q. Xiong, "Solar sorption cooling systems for residential applications: options and guidelines ' mes de refroidissement a ' sorption solaire pour les Syste ' sidentielles: options et recommandations applications re," International Journal of Refrigeration, vol. 32, pp. 638-660, 2009.

[12] C. Balaras, G. Grossman, H.-M. Henning et al., "Solar air conditioning in Europe - an overview," Renewable and Sustainable Energy Reviews, vol. 11, pp. 299-314, 2007.

[13] M. Izquierdo, M. Venegas, P. Rodríguez, and A. Lecuona, "Crystallization as a limit to develop solar air-cooled LiBrH2O absorption systems using low-grade heat," Solar Energy Materials \& Solar Cells, vol. 81, pp. 205-216, 2004.

[14] F. J. Cabrera, A. Fernández-García, S. RMP, and M. Pérez-García, "Use of parabolic trough solar collectors for solar refrigeration and air-conditioning applications," Renewable and Sustainable Energy Reviews, vol. 20, pp. 103-118, 2013.

[15] A. Pongtornkulpanich, S. Thepa, M. Amornkitbamrung, and C. Butcher, "Experience with fully operational solar-driven 
10-ton $\mathrm{LiBr} / \mathrm{H} 2 \mathrm{O}$ single-effect absorption cooling system in Thailand," Renewable Energy, vol. 33, pp. 943-949, 2008.

[16] X. Zhang, S. You, W. Xu, M. Wang, T. He, and X. Zheng, "Experimental investigation of the higher coefficient of thermal performance for water-in-glass evacuated tube solar water heaters in China," Energy Conversion and Management, vol. 78, pp. 386-392, 2014.

[17] R. Tang, Y. Yang, and W. Gao, "Comparative studies on thermal performance of water-in-glass evacuated tube solar water heaters with different collector tilt-angles," Solar Energy, vol. 85, pp. 1381-1389, 2011.

[18] L. J. Shah and S. Furbo, "Theoretical flow investigations of an all glass evacuated tubular collector," Solar Energy, vol. 81, pp. 822-828, 2007.

[19] F. Agyenim, I. Knight, and M. Rhodes, "Design and experimental testing of the performance of an outdoor $\mathrm{LiBr} / \mathrm{H} 2 \mathrm{O}$ solar thermal absorption cooling system with a cold store," Solar Energy, vol. 84, pp. 735-744, 2010.

[20] M. Ortiz, H. Barsun, H. He, P. Vorobieff, and A. Mammoli, "Modeling of a solar-assisted HVAC system with thermal storage," Energy and Buildings, vol. 42, pp. 500-509, 2010.

[21] A. H. H. Ali, P. Noeres, and C. Pollerberg, "Performance assessment of an integrated free cooling and solar powered single-effect lithium bromide-water absorption chiller," Solar Energy, vol. 82, pp. 1021-1030, 2008.

[22] K. Sumathy and Z. HuangZ. Li, "Solar absorption cooling with low grade heat source - a strategy of development in South China," Solar Energy, vol. 72, pp. 155-165, 2002.

[23] Z. He, N. Zhu, F. Liu, and S. Guo, "Design and performance of a solar absorption air-conditioning and heat-supply system," Acta Energiae Solaris Sinica, vol. 22, pp. 6-11, 2001.

[24] J. Li, N. Bai, W. Ma, L. Xianhang, and X. Jiang, "Large solar powered air conditioning-heat pump system," Acta Energiae Solaris Sinica, vol. 27, pp. 152-158, 2006.

[25] X. Zhang, R. Zheng, X. Feng et al., "Two demonstrations of solar heating system and air-conditioning system in buildings in China," in Proceedings of ISES World Congress 2007, pp. 926-929, Beijing: Tsinghua University Press, 2007.

[26] L. Feng, D. Zhu, G. Xie, and G. Liu, "Performance and experiment of Beiyuan solar air conditioning system," Heating Ventilation AIR Conditioning, vol. 40, pp. 84-86, 2010.

[27] Z. Li, J. Nie, X. Zhang et al., "Application of solar cooling system in a campus library in Hainan, China," Energy Procedia, vol. 30, pp. 730-737, 2012.

[28] T. He, X. Zhang, Z. Huang, Y. Deng, L. Zhang, and C. Wang, Report for Solar Heating and Cooling System in Qingdao, 2008.

[29] T. He, X. Zhang, Z. Huang, Y. Deng, L. Zhang, and C. Wang, Test Report for Solar Heating and Cooling System in Dalian, 2012.

[30] T. He, X. Zhang, C. Wang et al., "Application of solar thermal cooling system driven by low temperature heat source in China," Energy Procedia, vol. 70, pp. 454-461, 2015.

[31] A. Syed, M. Izquierdo, P. Rodríguez et al., "A novel experimental investigation of a solar cooling system in Madrid," International Journal of Refrigeration, vol. 28, pp. 859-871, 2005.

[32] S. Rosiek and F. J. Batlles, "Integration of the solar thermal energy in the construction: analysis of the solar-assisted airconditioning system installed in CIESOL building," Renewable Energy, vol. 34, pp. 1423-1431, 2009.

[33] Z. F. Li and K. Sumathy, "Experimental studies on a solar powered air conditioning system with partitioned hot water storage tank," Solar Energy, vol. 71, pp. 285-297, 2001.
[34] J. P. Praene, O. Marc, F. Lucas, and F. Miranville, "Simulation and experimental investigation of solar absorption cooling system in Reunion Island," Applied Energy, vol. 88, pp. 831-839, 2011.

[35] A. Mammoli, P. Vorobieff, H. Barsun, R. Burnett, and D. Fisher, "Energetic, economic and environmental performance of a solar-thermal- assisted HVAC system," Energy and Buildings, vol. 42, pp. 1524-1535, 2010.

[36] M. D. Moldovan, I. Visa, M. Neagoe, and B. G. Burduhos, "Solar heating \& cooling energy mixes to transform low energy buildings in nearly zero energy buildings," Energy Procedia, vol. 48, pp. 924-937, 2014.

[37] A. Gallo, B. T. Molina, M. Prodanovic, J. G. Aguilar, and M. Romero, "Analysis of net zero-energy building in Spain. Integration of PV, solar domestic hot water and air-conditioning systems," Energy Procedia, vol. 48, pp. 828-836, 2014.

[38] X. Zhang, W. Xu, T. He et al., "Solar thermal system evaluation in China," International Journal of Photoenergy, vol. 2015, Article ID 163808, 12 pages, 2015. 

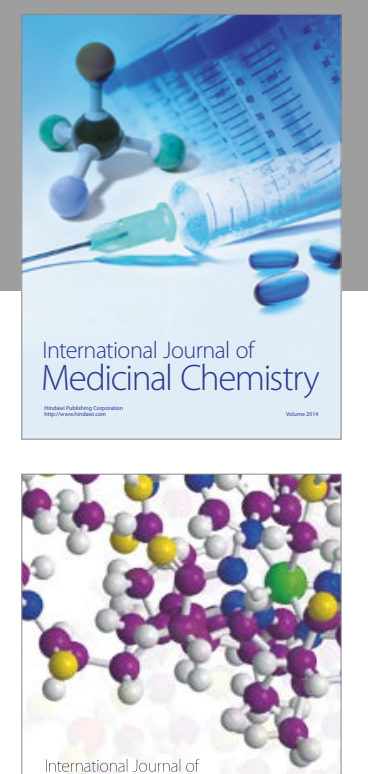

Carbohydrate Chemistry

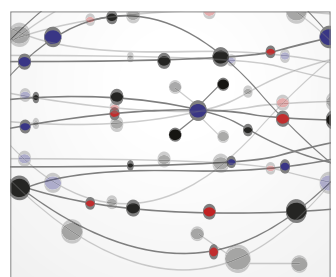

The Scientific World Journal
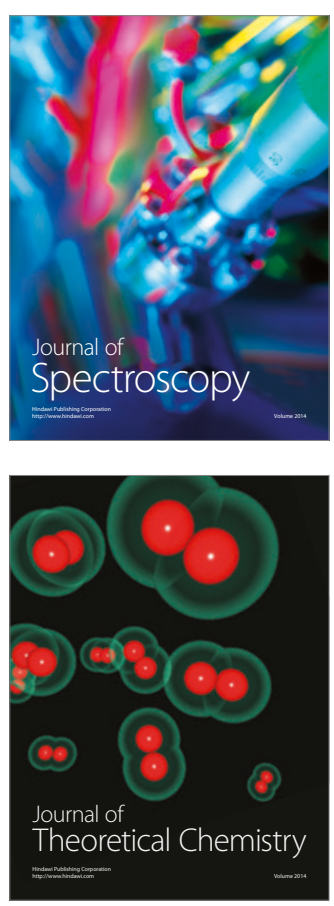
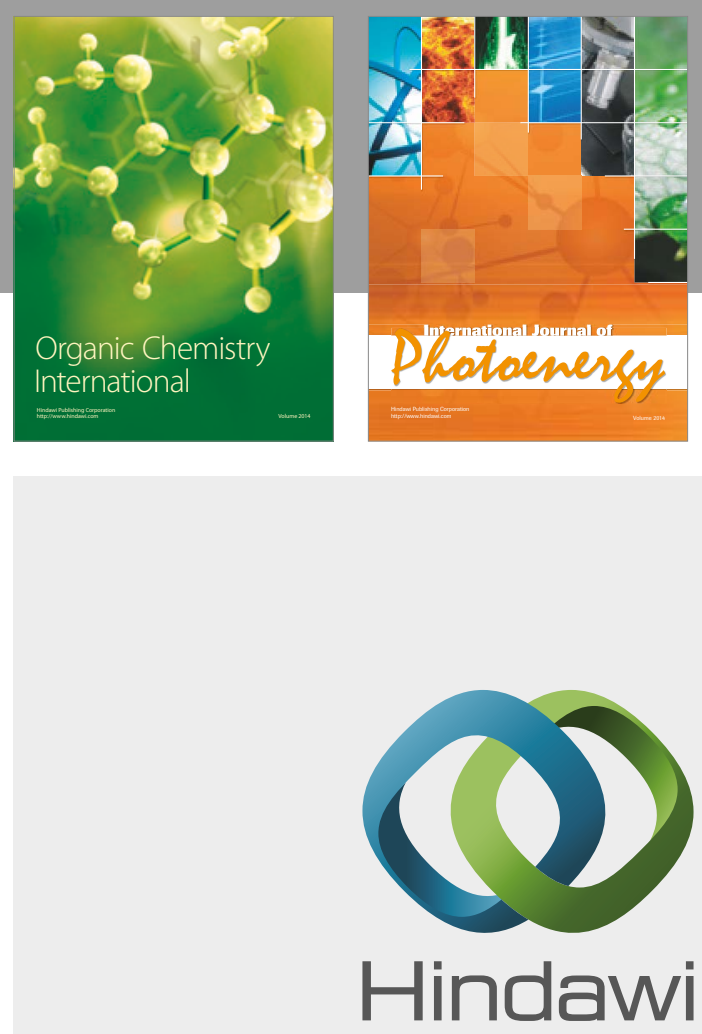

Submit your manuscripts at

https://www.hindawi.com

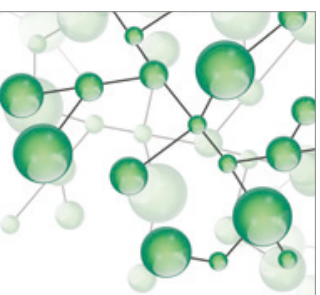

International Journal of

Inorganic Chemistry

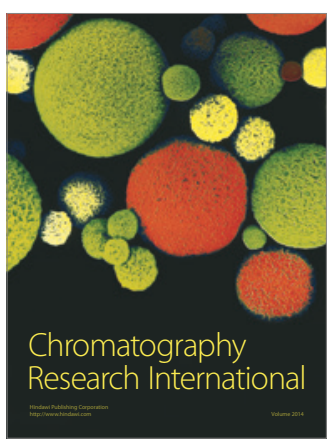

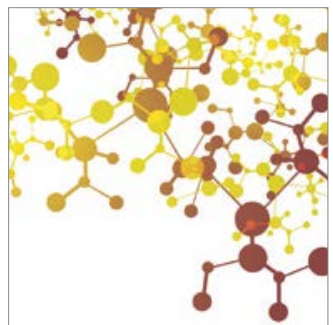

Applied Chemistry
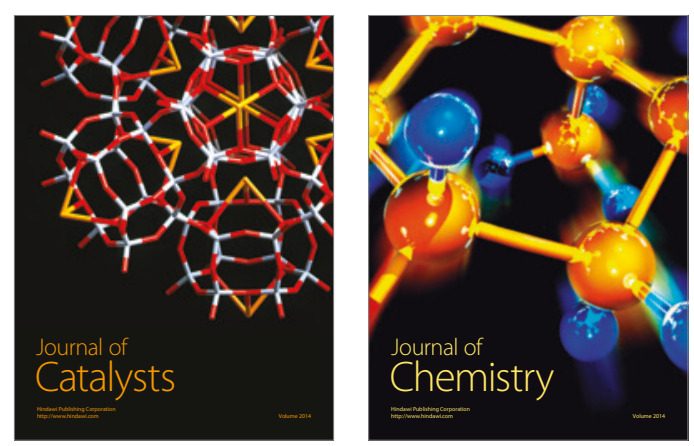
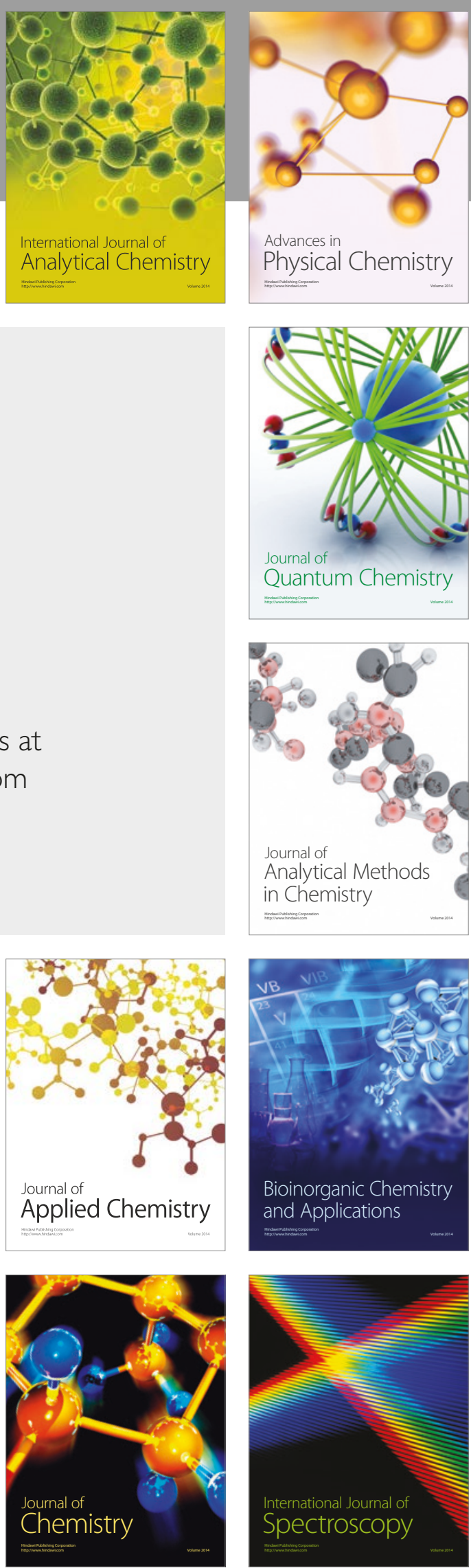